\title{
Tissue-Specific Processing of the Neuroendocrine Protein VGF
}

\author{
E. Trani, *T. Ciotti, A. M. Rinaldi, N. Canu, †G. L. Ferri, *A. Levi, and R. Possenti \\ Departimento di Medicina Sperimentale e Scienze Biochimiche, Università di "Tor Vergata"; *Istituto di Neurobiologia, \\ C.N.R., Roma; and $\dagger$ Neuro-Endocrine Research, University Department of Cytomorphology Cagliari, \\ and "Oasi" Clinical and Research Institute (IRCCS), Troina EN, Italy
}

\begin{abstract}
VGF is a neuroendocrine-specific gene product that is up-regulated by nerve growth factor in the PC12 cell line. In rat neuroendocrine tissues two polypeptides of 90 and $80 \mathrm{kDa}$ were detected by an antiserum to an $\mathrm{N}$-terminal domain of VGF (from residues 4 to 240). In parallel, an antiserum directed against the C-terminal nonapeptide of VGF (from residues 609 to 617 ) revealed several additional posttranslational products. Peptides of apparent molecular sizes of 20,18 , and $10 \mathrm{kDa}$ were prominent in nerve tissues and the hypophysis but absent in the adrenal medulla, and their relative abundance varied in distinct regions of the CNS. In PC12 cells VGF was proteolytically processed only after nerve growth factor treatment, and primary cultures of rat cerebellar granule cells accumulated the low-molecular-weight forms of VGF during in vitro maturation. In these cells the specific cleavages of VGF occurred in a postendoplasmic reticulum compartment; the processed forms were enriched in the secretory vesicles and were preferentially secreted upon cell membrane depolarization. Distinct differential distribution in the CNS and in vitro release of such posttranslational products indicate that these species may represent biologically relevant forms of VGF that play a role in neuronal communication. Key Words: VGFNerve growth factor-Prohormone processing-Secretory pathway - Neuronal differentiation-Cerebellar granule cells.
\end{abstract}

J. Neurochem. 65, 2441-2449 (1995).

The VGF gene was originally identified in the PC12 cell line because of its transcriptional induction by nerve growth factor (NGF) (Levi et al., 1985). It has been previously demonstrated that VGF protein is stored in secretory granules (Ferri et al., 1995) and in $\mathrm{PC} 12$ cells is secreted through the regulated pathway (Possenti et al., 1989).

In vivo VGF was detected in subpopulations of neuronal and endocrine cells (van den Pol et al., 1989, 1994: Ferri et al., 1992). In the cerebellum highest VGF mRNA levels were measured during the postnatal critical period of morphological and functional devel- opment (Salton et al., 1991). Recently, on the basis of RNase protection assays and immunocytochemistry, VGF was demonstrated to be spatially and temporally regulated in the CNS during the development of the rat visual system (Lombardo et al., 1995). VGF mRNA is first detected in the dorsal lateral geniculate nucleus at day 18 of embryonic development, when connections from the dorsal lateral geniculate nucleus to the visual cortex are formed. VGF gene expression increases gradually in the first 2 weeks postnatally, when synapses with definitive target neurons are established, and then gradually decreases at the end of the plasticity period. In the rat adenohypophysis, VGF protein was restricted to gonadotropes and a subpopulation of lactotropes with striking modulation during the estrous cycle (Ferri et al., 1995). In the adult rat several experimental manipulations, which increase transcription in the CNS of mRNA for secretory proteins like secretogranin II and chromogranin B, affect the expression of VGF mRNA in a similar way (M. Mahata et al., 1993; S. K. Mahata et al., 1993a,b).

The presence of several short stretches of basic residues, potential target sites for proteases of the subtilisin family (Steiner et al., 1992), in the sequence of VGF suggests that the protein may be the precursor of shorter neuropeptides. To investigate the possible processing of VGF protein to smaller polypeptides, preliminary studies were carried out, using previously characterized antisera raised against two nonoverlapping domains of the VGF sequence (from residues 80 to 340 and from 443 to 580 ) (Possenti et al., 1989; Ferri et al., 1992). Both antisera, in western blots, recognized two proteins with apparent molecular sizes

Received April 20, 1995; revised manuscript received June 13, 1995; accepted June 13, 1995.

Address correspondence and reprint requests to Dr. A. Levi at Istituto di Neurobiologia, C.N.R., Viale Marx 43/15, 00137 Roma, Italy.

Abbreviations used: BFA, brefeldin A; DIV, days in vitro; ECL enhanced chemiluminescence; FCS, fetal calf serum; NGF, nerve growth factor; PAGE, polyacrylamide gel electrophoresis; PBS, phosphate-buffered saline; SDS, sodium dodecyl sulfate. 
of 90 and $80 \mathrm{kDa}$. These values are slightly higher than those expected from the amino acid sequence of the protein but are similar to the apparent molecular mass of the cell-free translated VGF (Levi et al., 1985). In addition, the antiserum directed against the more COOH-terminal region stained several shorter polypeptides, suggesting that proteolytic products of VGF were derived from the $\mathrm{C}$-terminal region. When further VGF antisera were tested, two showed high sensitivity and were selected for the characterization of VGF products in rat tissues and cell lines.

The data reported here show that three major polypeptides, which are derived from the VGF C-terminal region, are found in neuronal tissues as posttranscriptional endoproteolytic cleavage products. In primary cultures of rat cerebellar granule cells, the processing of VGF occurs in a postendoplasmic reticulum compartment, and the resulting products are preferentially accumulated in secretory vesicles from which they are released upon cell membrane depolarization.

\section{MATERIALS AND METHODS}

\section{Materials}

All the chemicals, when not specified, were purchased from Sigma Chemical Co. (St. Louis, MO, U.S.A.). Media, sera, and phosphate-buffered saline (PBS) were purchased from GIBCO (Grand Island, NY, U.S.A.). The enhanced chemiluminescence (ECL) system was purchased from Amersham International plc (Buckinghamshire, U.K.).

\section{Production of antisera}

The polyclonal antiserum anti- $\mathrm{VGF}_{4.240}$ was raised in rabbits against recombinant VGF produced in Escherichia coli using the expression system described by Sisk et al. (1986). In brief, the sequence coding for residues 4-240 of VGF was excised as an Xmn fragment from a cDNA clone and inserted in the $N r u$ l site of plasmid pWS50. The strain of $E$. coli WPS18 transformed with this plasmid produced high levels of VGF fused in-frame with $\beta$-galactosidase when induced by temperature shift. Bacterial lysates were resolved on sodium dodecyl sulfate (SDS) - polyacrylamide gel electrophoresis (PAGE). The fusion band was detected in Coomassie Brilliant Blue-stained gels, eluted with $50 \mathrm{~m} M$ $\mathrm{NH}_{4} \mathrm{HCO}_{3}$ containing $0.1 \%$ SDS, precipitated with $20 \%$ trichloroacetic acid, and resuspended in PBS for immunization of rabbits.

The anti- $\mathrm{VGF}_{6019-617}$ serum was raised in rabbits against the corresponding $C$-terminal sequence of rat VGF, as previously described in detail (Ferri et al., 1995).

\section{Cell lines}

PC 12 cells were grown on collagen-coated dishes in RPMI medium supplemented with $10 \%$ heat-inactivated horse serum and $5 \%$ fetal calf serum (FCS) as described (Greene and Tischler, 1976). Where indicated, PCl2 cells were treated with $1(00) \mathrm{ng} / \mathrm{ml}$ of $\beta-\mathrm{NGF}$, kindly provided by Dr. D. Mercanti. GT 1-7, AtT20, MTC 6-23, GH3, and NIH$3 T 3$ cell lines were grown in Dulbeco's modified Eagle's medium containing $10 \%$ FCS. Cells were cultured in a $95 \%$ air $/ 5 \% \mathrm{CO}_{2}$ humidified $37^{\circ} \mathrm{C}$ incubator.

GT 1-7 cells were kindly provided by Dr. Stanko S. Stojil- kovic. The other cell lines were obtained from the American Type Culture Collection (Rockville, MD, U.S.A.).

\section{Primary cultures of cerebellar granule cells}

The cultures were performed as described (Levi et al., 1984). In brief, cells dissociated from 8-day-old rat cerebella were plated on polylysine-coated dishes at a density of $2.5-$ $2.8 \times 10^{6}$ cells per 35 -mm-diameter dish in basal modified Eagle's medium supplemented with $10 \%$ heat-inactivated FCS. The medium was renewed at 2, 5, and 8 days in vitro (DIV). Release experiments were performed on 8 DIV cultures as described (Mercanti et al., 1992). The culture dishes were washed twice with prewarmed Krebs-Ringer medium $(128 \mathrm{~m} M \mathrm{NaCl}, 5 \mathrm{~m} M \mathrm{KCl}, 2.7 \mathrm{mMCaCl}, 1.2 \mathrm{~m} M$ $\mathrm{MgSO}_{4}, 10 \mathrm{mM}$ glucose, $1 \mathrm{~m} M \mathrm{Na}_{2} \mathrm{HPO}_{4}$, and $20 \mathrm{~m} M$ HEPES, $\mathrm{pH} 7.4$ ) and preincubated in the same medium for $30 \mathrm{~min}$ at $37^{\circ} \mathrm{C}$. Secretion was induced for $15 \mathrm{~min}$ by adding a Krebs-Ringer solution containing either $56 \mathrm{mM} \mathrm{KCl}$ and $77 \mathrm{~m} M \mathrm{NaCl}$ or $0.25 \mu M$ ionomycin (Graham and Burgoyne, 1993). Experiments with $2 \mu \mathrm{g} / \mathrm{ml}$ of brefeldin A (BFA) were performed at 8 DIV.

\section{Immunofluorescence}

Cerebellar granule cells were washed three times in PBS and fixed for $10 \mathrm{~min}$ in $4 \%(\mathrm{wt} / \mathrm{vol}$ in PBS ) paraformaldehyde. The cells were then permeabilized for $5 \mathrm{~min}$ with $0.2 \%$ (vol/vol) Triton $\mathrm{X}-100$ in $100 \mathrm{~m} M$ Tris- $\mathrm{HCl}$ ( $\mathrm{pH} 7.5$ ). Incubation with primary antisera was carried out at room

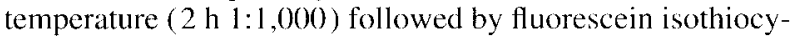
anate-conjugated goat anti-rabbit $\operatorname{IgG}(30 \mathrm{~min})$ according to the manufacturer's instructions.

\section{Cell and tissue extraction}

Cell lines and tissues, immediately after dissection from rats, were homogenized in distilled water at $0^{\circ} \mathrm{C}(1 \mathrm{ml}$ for $100 \mathrm{mg}$ ), quickly boiled for $10 \mathrm{~min}$, and then centrifuged for 5 min at $2,500 \mathrm{~g}$. Addition of $1 \mathrm{~m} M$ phenylmethylsulfonyl fluoridc, $20 \mu \mathrm{g} / \mathrm{ml}$ of leupeptin, and $0.2 \mu \mathrm{g} / \mathrm{ml}$ of pepstatin A did not affect the pattern of immunoreactive bands, so that the protein inhibitors could be omitted. The pellets were extracted in $0.2 \%$ acetic acid, boiled for $5 \mathrm{~min}$, and then centrifuged for $5 \mathrm{~min}$ at $2,500 \mathrm{~g}$. The two supernatants were combined and centrifuged for $30 \mathrm{~min}$ at $100,000 \mathrm{~g}$. The proteins in the supernatants were precipitated by $15 \%$ trichloroacetic acid. For one-dimensional electrophoresis ( see below) the samples were solubilized in $2 \%$ SDS and $8 M$ urea in $10 \mathrm{~m} M$ Tris- $\mathrm{HCl}(\mathrm{pH} 8.2)$, and protein content was determined according to the method of Lowry et al. (1951).

\section{One- and two-dimensional electrophoresis}

One-dimensional SDS-PAGE was performed on a 7.5 $20 \%$ acrylamide gradient according to the procedure of Laemmli (1970). For the two-dimensional analysis, the proteins were first resolved by isoelectrofocusing as described (Eboli et al., 1994) and then electrophoresed on the gradient of polyacrylamide as described above.

\section{Western blotting}

Gels were analyzed by the western blot procedure according to the technique of Burnette (1981). Blotted membranes were incubated with a $1: 1,000$ dilution of anti-VGF antisera and subsequently probed with horseradish peroxidase-conjugated protein $\mathrm{A}$. The immunoblots were developed by the ECL system. Protein sizes were determined by comparison with prestained molecular weight standards 
A

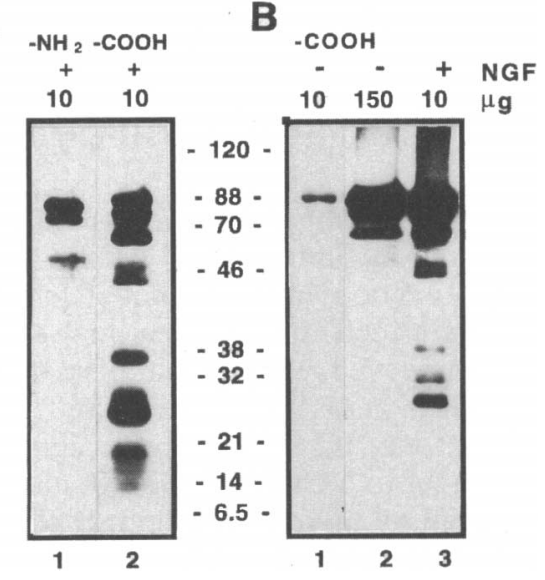

FIG. 1. Western blot analysis of PC12 cell extracts with different antisera against VGF. A: Extracts of PC12 cells treated with 100 $\mathrm{ng} / \mathrm{ml}$ of NGF for $48 \mathrm{~h}$ were examined with anti-VGF ${ }_{4-240}$ serum, which recognizes the most $\mathrm{N}$-terminal region of VGF (lane 1), or anti-VGF $\mathrm{VGg-617}$ serum, raised against the last nine residues of VGF (lane 2) $(10 \mu \mathrm{g}$ of protein per lane). B: Cell extracts of untreated PC12 cells (lanes 1 and 2) or cells exposed to NGF for $48 \mathrm{~h}$ (lane 3 ) were examined with anti-VGF $\mathrm{VG}_{609-617}$ serum. Lanes 1 and 3 were loaded with $10 \mu \mathrm{g}$ of total proteins and lane 2 with $150 \mu \mathrm{g}$ of total proteins, to obtain approximately the same amount of VGF precursor forms.

(Sigma and Amersham). Scanning of ECL detections was performed as described (Ferri et al., 1995).

\section{RESULTS}

\section{Antisera against the $\mathrm{COOH}$-terminal domain of VGF reveal proteolytically processed forms in NGF-treated PC12 cells}

An antiserum directed against an $\mathrm{N}$-terminal portion of VGF (anti-VGF ${ }_{4-240}$ ) recognizes, in western blot analysis of $\mathrm{PC} 12$ cell extracts, polypeptides of apparent molecular sizes of 90, 80, and $50 \mathrm{kDa}$ (Fig. 1A, lane 1). All these molecular forms were greatly induced (10-20-fold) by treatment with NGF. When the Cterminal anti- $\mathrm{VGF}_{609-617}$ serum was used, a very different pattern of immunoreactivity was revealed. In addition to the high-molecular-mass forms of 90 and 80 $\mathrm{kDa}$, several lower-molecular-mass polypeptides were detected, ranging from 70 to $10 \mathrm{kDa}$ (Fig. 1A, lane 2). Staining of all bands was abolished by preadsorption of anti-VGF $\mathrm{V}_{(09)} 617$ serum on lysates of VGF-producing bacteria but not by preadsorption on control bacteria (data not shown). The bands recognized by the anti$V_{G F} F_{6(1)-617}$ serum are most probably derived from VGF because the same pattern of immunoreactive bands was obtained with a different antiserum raised against a $\mathrm{COOH}$-terminal domain of VGF ( from amino acid 572 to 617) (data not shown) and because all the polypeptides recognized by the antisera were the products of a NGF-inducible gene. The translated region of VGF is encoded by a single exon (Salton et al., 1991; Hawley et al., 1992); therefore, the different forms detected by the antisera cannot be accounted for by differential splicing and must be the consequence of posttranslational processing.

PC12 cells that had not been treated with NGF did not process the high-molecular-weight forms of VGF into shorter polypeptides. Lower-molecular-weight species were not revealed in extracts of naive $\mathrm{PCl} 2$ cells ( Fig. 1B, lane 2), even if greater amounts of total proteins from untreated than from NGF-treated cells were loaded to detect comparable amounts of the 90)and 80-kDa forms (Fig. 1B, lanes 2 and 3).

Therefore, NGF-induced PC12 cell differentiation led to increased synthesis of VGF and also to VGF processing.

\section{VGF is proteolytically processed in the rat CNS}

To determine whether VGF processing occurs also in vivo, extracts from different tissues of adult animals were examined by western blot analysis (Fig. 2). In agreement with previous findings, based on in situ hybridization and immunohistochemical techniques (van den Pol et al., 1989, 1994), VGF immunoreactivity was detected in extracts from nerve tissues (whole brain and cerebellum) and was undetectable in several nonnervous tissues (Fig. 2A). Anti-VGF $\mathrm{VG}_{613-617}$ serum recognized, in adult brain extracts, a subset of the bands detected in PC12 cells: Beside the 90- and 80kDa polypeptides, only a few lower-molecular-mass polypeptides were stained. Between them the most abundant were proteins of 20,18 , and $10 \mathrm{kDa}$. These proteins will be referred to as VGF-90, VGF-80, VGF20, VGF-18, and VGF-10, respectively. Different areas within the adult rat CNS contained different amounts of the high- and low-molecular-weight forms of VGF (Fig. 2B). In particular, VGF-20 and VGF-18 were abundant species in the majority of the regions examined with the exception of the olfactory bulb and the pons, whereas VGF-10 was present at a relatively high level only in the cortex and pons (Fig. 2C). Intermediate-molecular-weight polypeptides were only a minor component in extracts of CNS compared with NGFtreated $\mathrm{PC} 12$ cells (see next section and Discussion).

\section{VGF is synthesized but not processed in the adrenal medulla}

PC12 cells originate from a rat pheochromocytoma, and it has been demonstrated that chromaffin cells from the adrenal medulla express VGF (Ferri et al., 1992). It was therefore of interest to determine if VGF is processed in this gland as it is in neuronal tissues. As shown in Fig. 3, VGF protein was present in chromaffin cells almost exclusively as the high-molecularweight forms, and no low-molecular-weight form was detectable. Two-dimensional electrophoresis of adrenal medulla and PC12 cell extracts shows virtually superimposable patterns of VGF-immunoreactive peptides. Conversely, a comparison between NGF-treated PC12 cells and adult brain indicated that quantitative as well as qualitative differences exist and that $\mathrm{PC} 12$ cells seemed unable to convert VGF completely into 
A
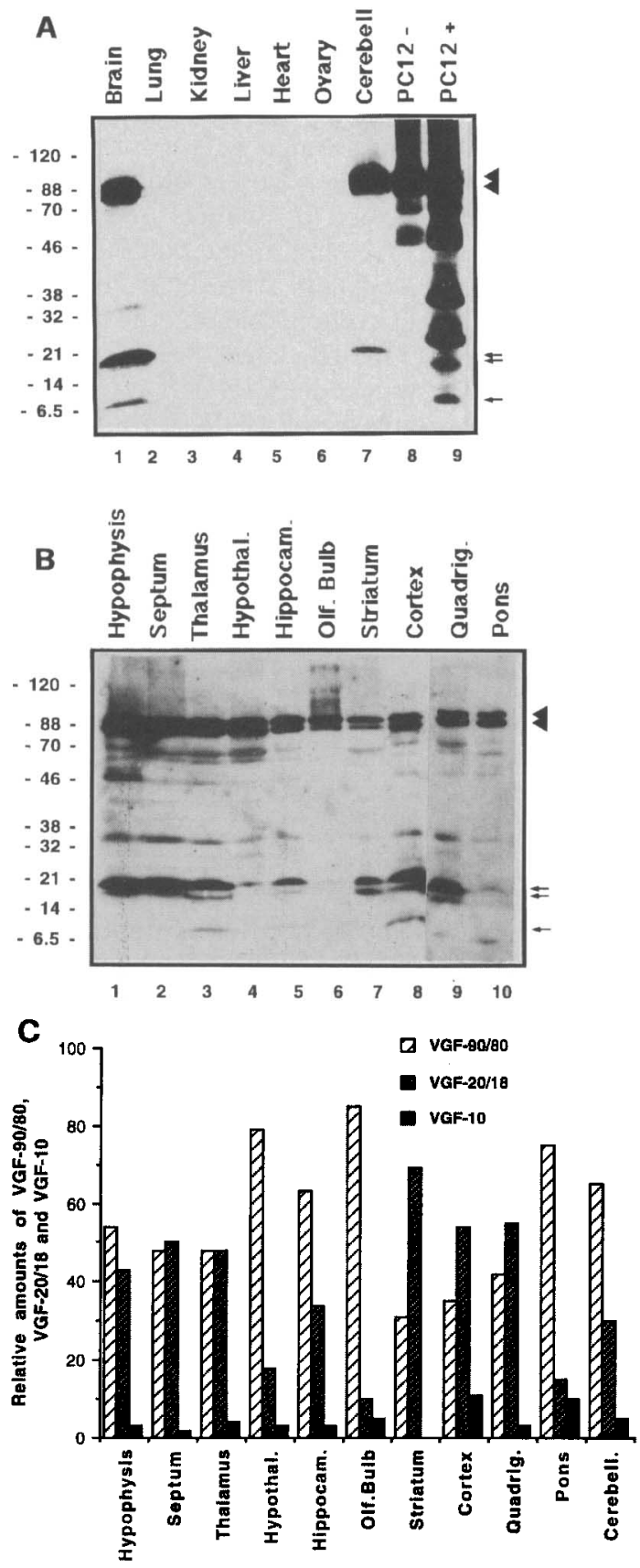

FIG. 2. Western blot analysis of extracts from different tissues. Tissue extracts ( $250 \mu \mathrm{g}$ of protein per lane) were analyzed for the presence of VGF. A: Extracts from different organs. B: Extracts from different areas of the CNS. The tissues were dissected from adult rats (60-90 days old). PC12- and PC12+ represent total extracts from naive or NGF-treated cells (100 and $20 \mu \mathrm{g}$, respectively). The forms of 90 and $80 \mathrm{kDa}$ are indicated by arrowheads, and the major products of VGF processingVGF-20, VGF-18, and VGF-10- are indicated by arrows. C: Relative amounts of VGF-90, VGF-80, VGF-20, VGF-18, and VGF10 as determined by densitometric scannings of blots. The signals from VGF-90 and VGF-80 and from VGF-20 and VGF-18 were added together. Scanning on three independent western blots gave differences not exceeding $10 \%$ of each value. Cerebell., cerebellum; Hypothal., hypothalamus; Hippocam., hippocampus; Olf.Bulb, olfactory bulb; Quadrig., quadrigeminum. the low-molecular-weight peptides. In particular, immunoreactive polypeptides of intermediate size were present and probably represented partially digested products that all contain the $\mathrm{COOH}$-terminus ( see also Fig. 1).

\section{Neuronal and endocrine cell lines and primary} cultures of cerebellar granule cells

To identify good in vitro models for VGF processing, several cell lines of neuronal and endocrine origin were surveyed. The two pituitary-derived rodent cell lines GH3 and AtT-20 expressed VGF-90 and VGF-80, but only the AtT-20 cells significantly process the protein to VGF-20, VGF-18, and VGF-10. A murine medullary thyroid carcinoma cell line (MTC) and a hypothalamic murine cell line (GT1-7) also contained detectable quantities of VGF-90 and VGF-80 as well as of VGF-20, VGF-18, and VGF-10. No immunoreactive band was detected in extracts of NIH3 T3 cells (Fig. 4A) or in other nonneuronal and nonendocrine cell lines tested (data not shown). In view of the presence of VGF-20, VGF-18, and VGF-10 in extracts of rat cerebellum (Fig. 2C), primary cultures of cerebellar granule cells were examined. Cultures of granule cells from 8-day-old rat cerebella have been shown to represent an established model for the study of neuronal maturation because they acquire, gradually with time in vitro, morphological and functional properties of differentiated neurons (Levi and Ciotti, 1983; Levi et al., 1984). As shown in Fig. 4B, immunoreactive VGF-90 and VGF-80 were first detected around day 2 in culture ( 2 DIV), whereas the VGF-derived peptides were not present before 5 DIV; their relative levels increased at later times in culture ( 8 DIV) when granule cells have acquired a mature phenotype (see also Fig. 6a-d).

\section{VGF processing is inhibited by BFA}

Because VGF is accumulated in secretory granules and is released on cell depolarization (Possenti et al., 1989), the endoproteolytic cleavages that result in the production of VGF-20, VGF-18, and VGF-10 must occur in some compartment of the secretory pathway. The fungal metabolite BFA is used for interrupting the vesicular vectorial transport of protein toward the cell surface. BFA is believed to act by preventing the correct assembly of COP (coat-proteins) - and clathrincoated vesicles, thus causing an accumulation in the endoplasmic reticulum of proteins en route to other compartments of the secretory pathway (Klausner et al., 1992; Robinson and Kreis, 1992). In mature cerebellar granule cells ( 8 DIV) treated with BFA, the amount of VGF-90 increased, whereas levels of VGF80, VGF-20, VGF-18, and VGF-10 peptides decreased (Fig. 5). This phenomenon, already evident after $6 \mathrm{~h}$ of treatment with BFA (lane 2), was almost complete after $20 \mathrm{~h}$ (lane 3 ).

\section{C-Terminal VGF-derived peptides are enriched in} secretory granules and are secreted

As reported above, several VGF peptides showed differential reactivity with the $\mathrm{N}$ - and $\mathrm{C}$-terminal anti- 
FIG. 3. Comparison by two-dimensional electrophoresis of VGF-immunoreactive polypeptides in $\mathrm{PC} 12$ cells, brain, and adrenal medulla. Cell extracts from PC12 cells or PC12 cells treated with NGF for $48 \mathrm{~h}$ ( 100 and $20 \mu \mathrm{g}$ of proteins, respectively) and from adrenal medulla and brain of adult rats $(250 \mu \mathrm{g}$ of proteins) were resolved by two-dimensional electrophoresis as described in Materials and Methods and probed with anti-VGF $609-617$ serum. I.E.F., isoelectrofocusing.
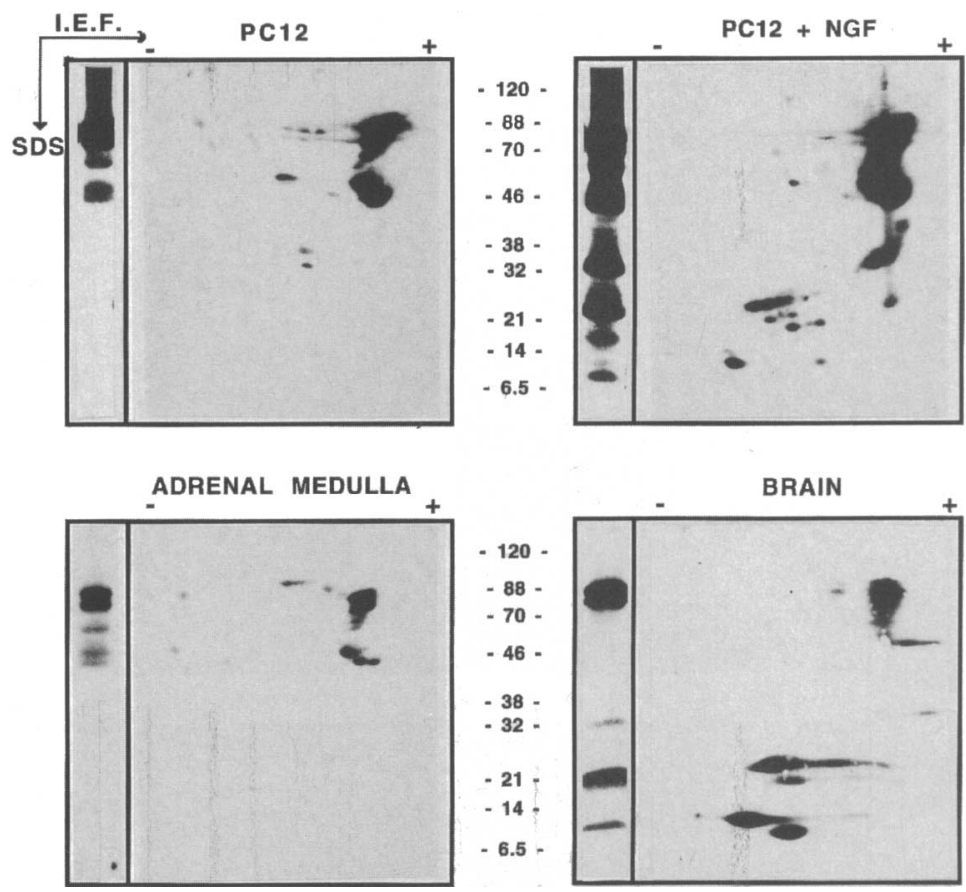

sera used (anti-VGF $\mathrm{VG}_{609-617}$ serum recognized VGF-90, VGF-80, VGF-20, VGF-18, and VGF-10, whereas anti-VGF ${ }_{4-240}$ serum recognized only VGF-90 and VGF-80). Therefore, staining revealed by $\mathrm{C}$-terminal antiserum is diagnostic of the presence of the processed forms in the absence of the high-molecular-weight VGF. In immunofluorescence, anti-VGF ${ }_{4-249}$ serum

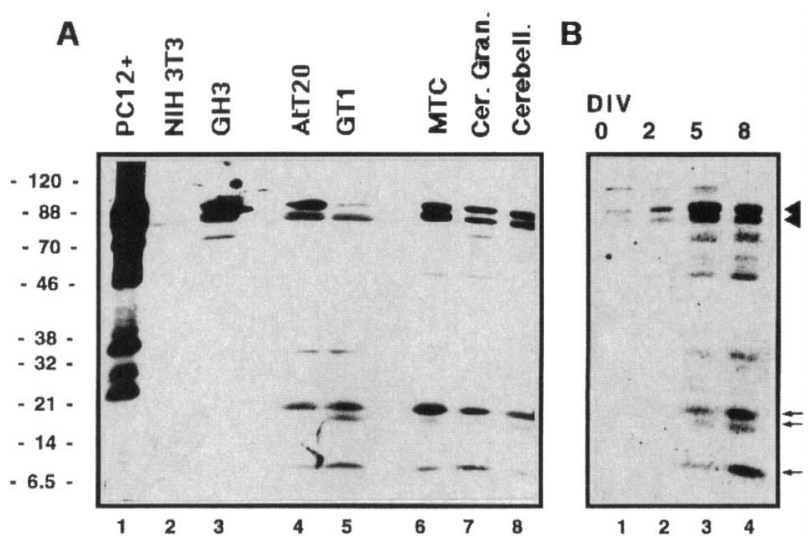

FIG. 4. Western blot analysis of extracts from different cell lines and primary cultures of cerebellar granule cells. A: Extracts of different rodent cell lines and from cultured rat cerebellar granule cells (Cer. Gran.) at 8 DIV were probed in western blot analysis with anti-VGF ${ }_{609-617}$ serum. Extract from adult rat cerebellum (Cerebell.) is shown for comparison. Protein contents were 20 $\mu \mathrm{g}$ for lane 1, 200 $\mu \mathrm{g}$ for lanes 4 and $5,250 \mu \mathrm{g}$ for lane 8 , and $100 \mu \mathrm{g}$ for the other lanes. B: Equal amounts of total proteins $(100 \mu \mathrm{g})$ from cerebellar granule cells cultured for different DIV, as indicated at the top, were examined for the presence of VGF90, VGF-80 (arrowheads), VGF-20, VGF-18, and VGF-10 (arrows). stained preferentially the cell bodies of cerebellar granule cells at 2 DIV (Fig. 6a), when western blot analysis has shown that no processed form is present (see Fig. $4 \mathrm{~B}$, lane 2), and also at 8 DIV (Fig. 6c), when the VGF protein is highly expressed and also processed (Fig. 4B, lane 4). In contrast, anti- $\mathrm{VGF}_{6\left(\mathfrak{y}^{\prime}-617\right.}$ serum stained the cell bodies at 2 DIV (Fig. 6b) but revealed a strong immunoreactivity of neuronal processes (as well as cell bodies) at 8 DIV (Fig. 6d). Overnight treatment with BFA, which causes accumulation of VGF-90 and decreases the level of the processed forms, resulted in a different pattern of VGF immunoreactivity in 8 DIV granule cells. Both antisera gave a strong staining limited to the perikaryal area with the exclusion of neuronal processes (Fig. 6e and f).

When mature cerebellar granule cells were subjected to secretory stimuli, like high potassium levels or calcium ionophore, VGF-20, VGF-18, and VGF-10 were preferentially secreted with respect to VGF-90 and VGF-80 (Fig. 7, compare lanes 3 and 5 vs. 4 and 6).

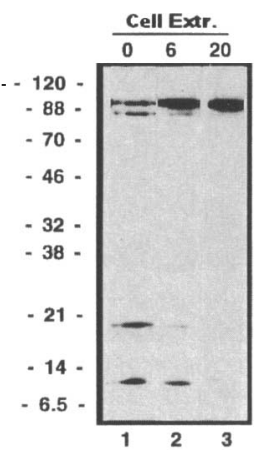

FIG. 5. Effect of treatment with BFA on the proteolytic processing of VGF. Western blot analysis with anti-VGF ${ }_{609-617}$ serum of cerebellar granule cells at 8 DIV treated with $2 \mu \mathrm{g} / \mathrm{ml}$ of BFA for different intervals, as indicated at the top (lane 1 , $0 \mathrm{~h}$; lane 2, $6 \mathrm{~h}$; and lane 3,20 h). Cell Extr., cell extract. 

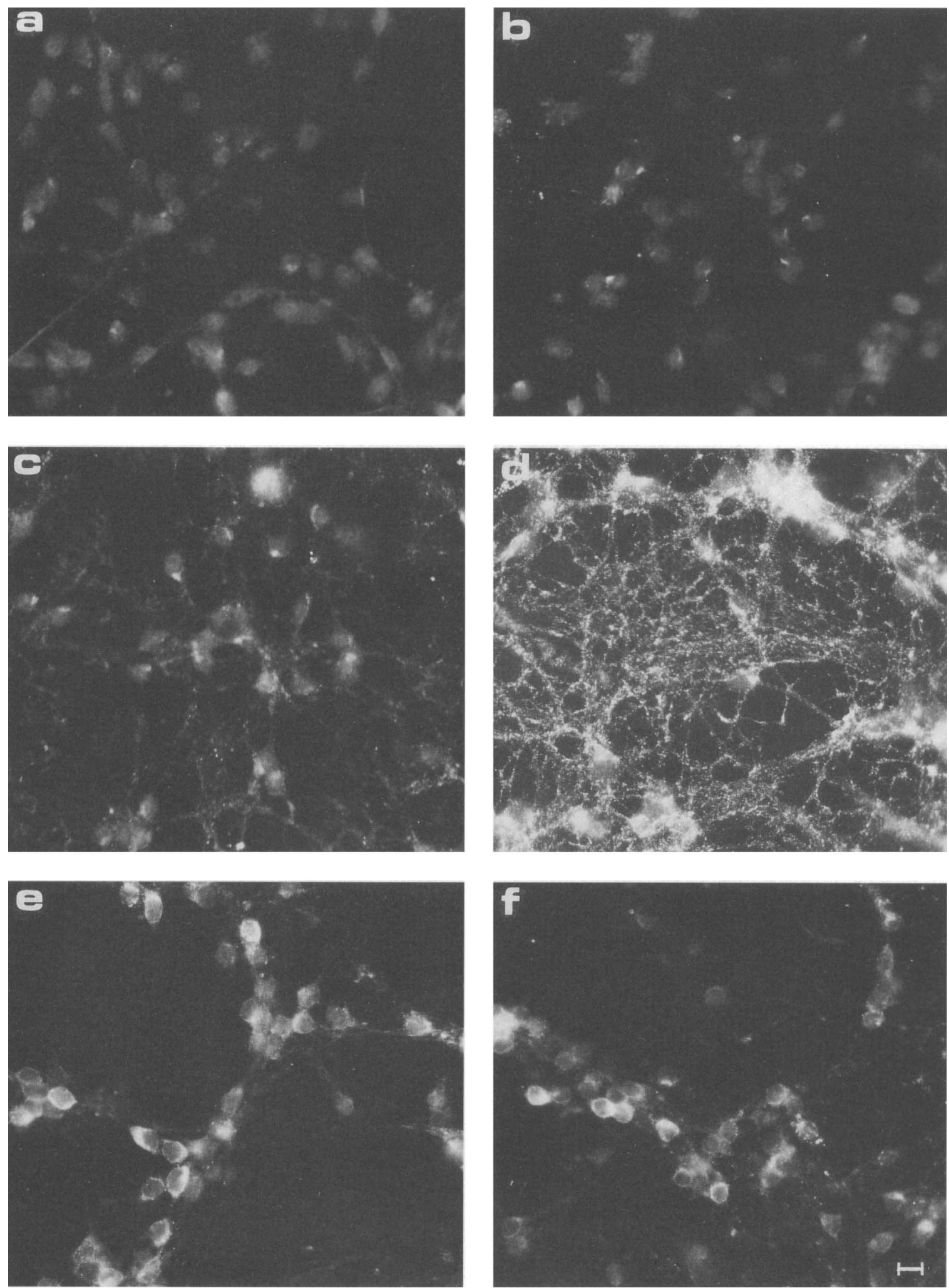

FIG. 6. Immunofluorescent staining of cultured cerebellar granule cells. Indirect immunofluorescence of granule cells is shown at 2 (a and b) or 8 DIV $(c-f)$. In (e) and (f) the cerebellar granule cells were treated with $2 \mu \mathrm{g} / \mathrm{ml}$ of BFA for $20 \mathrm{~h}$ before immunodetection. As primary antiserum, anti-VGF ${ }_{4-240}$ serum was used in (a), (c), and (e), and anti-VGF F09-617 serum was used in (b), (d), and (f). Goat anti-rabbit fluorescein isothiocyanate-conjugated lgG was used as secondary antibody. Bar $=5 \mu \mathrm{m}$. 


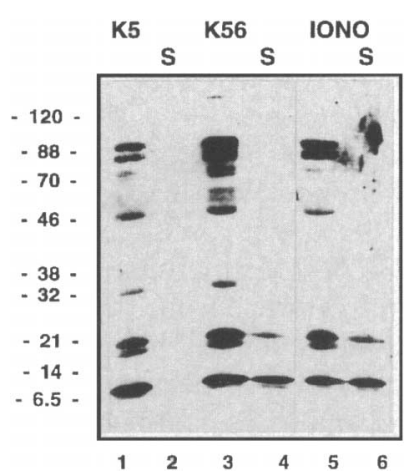

FIG. 7. Regulated secretion of VGF-20, VGF-18, and VGF-10 from primary cultures of cerebellar granule cells. In primary cultures of cerebellar granule cells at 8 DIV the secretion was induced by a high $\mathrm{KCl}$ concentration $(56 \mathrm{mM}$ ) or ionomycin (IONO) as described in Materials and Methods. Cell extracts and released proteins were examined by western blot with anti$\mathrm{VGF}_{609-617}$ serum. Lanes 1 and 2, cell extracts and secreted proteins into the medium from control cells [treated with $5 \mathrm{mM}$ $\mathrm{KCl}(\mathrm{K} 5)$ ]; lanes 3 and 4 , cell extracts and medium from cells exposed to high potassium [ $56 \mathrm{mM} \mathrm{KCl}(\mathrm{K} 56)$ ]; and lanes 5 and 6 , cell extracts and medium from IONO-treated cells. Half of the total cell extracts $(\sim 100 \mu \mathrm{g})$ from $2 \times 10^{6}$ cells and all the released material $(S)$ were electrophoresed on the gel.

\section{DISCUSSION}

The major finding of the present report is the demonstration that VGF protein is proteolytically processed in rat nervous tissues and that the derived peptides are stored in and released from mature secretory granules. Three major C-terminal-derived forms of 20,18 , and $10 \mathrm{kDa}$ apparent molecular sizes were detected. Regional differences exist in their relative amount as well as in their ratio to the high-molecular-weight forms (VGF-90) and VGF-80). This could be attributed to neuron-specific differences in the expression of converting enzymes. Alternatively, because these forms are strongly enriched in neuronal processes, whereas VGF-90 and VGF-80 are mainly present in the perikaryon, variation in the ratio between the high- and the low-molecular-weight species may reflect different densities of synaptic terminals in the brain areas examined. Prohormones and neuropeptide precursors are generally processed by ubiquitous and tissue-specific convertases in different compartments along the secretory pathway (Steiner et al., 1992). Because VGF processing does not occur, for instance, in the adrenal medulla, which nevertheless synthesizes detectable quantities of this protein, it is likely that neuronalspecific endoproteases are responsible for generating the low-molecular-weight species. The best-characterized neuroendocrine-specific convertases ( $\mathrm{PCl} / 3$ and PC2) have been shown to cleave their substrates at short stretches of basic residues. If either one or both of these convertases are responsible for processing of VGF is presently unknown, however, several potential target sites are present in the sequence of this protein (Salton et al., 1991), some of which would generate fragments of molecular size similar to the peptides described in this article.

The data have shown that the NGF-responsive cell line PC 12 cleaves pro-VGF only NGF-induced differentiation. Similarly, VGF-20, VGF-18, and VGF-10 are detectable in primary cultures of neonatal cerebellar granule cells only after in vitro maturation, with a time course delayed with respect to the expression of VGF-90 and VGF-80. Thus, the ability to process VGF appears to be a characteristic of neuronal maturation. In NGF-treated PC12 cells proteolytic conversion of VGF to the low-molecular-weight species occurs with reduced efficiency with respect to other cell lines, primary cell cultures, and neuronal tissues. The same findings were observed with $\mathrm{PC} 12$ cells cultured for 10 days with NGF (authors' unpublished data). It should be noted, however, that NGF-treated PC12 cells synthesize amounts of VGF that are at least one order of magnitude higher than in all tested cell lines and tissues. Such a high level of VGF might saturate the processing machinery of $\mathrm{PCl} 2$ cells, resulting in the accumulation of intermediate products that are fully digested in neurons. Alternative hypotheses can also be formulated: (a) Treatment with NGF may not be sufficient for inducing the complete repertoire of the neuronal-specific processing enzymes that are responsible for generating VGF-20, VGF-18, and VGF-10 in neurons of the CNS, or (b) treatment with NGF may induce the synthesis of convertases that are able to recognize VGF as a substrate, possibly with low specificity, but that are different from those present in neurons of the CNS.

The data indicate that treatment of mature ( 8 DIV) cultures of cerebellar granule cells with BFA prevents the proteolytic cleavage of VGF, which accumulates in a perinuclear compartment. This finding suggests that this processing occurs after VGF has left the endoplasmic reticulum. In fact, posttranslational modifications that are inhibited by BFA treatment are generally considered to occur in the trans-Golgi network or downstream of it (Rosa et al., 1992b). A postendoplasmic reticulum cleavage of pro-VGF is in agreement with the late processing of other prohormones. It has been shown, for instance, that the endoproteolytic cleavage of prosomatostatin is initiated in the transGolgi network, in a late acidic compartment, shortly before the nascent immature secretory granules are formed (Xu and Shields, 1993). It is noteworthy that treatment with BFA inhibits also the cleavage that produces the $80-\mathrm{kDa}$ form of VGF, which we have observed in every cell line and tissue that express the protein. This cleavage therefore is likely to be carried out by a ubiquitous convertase like, for instance, furin. It is interesting that this endoprotease has been recently shown to be selectively concentrated in the trans-Golgi network and to require transit through the Golgi to achieve functional activity (Molloy et al., 1994). Indirect immunofluorescence in primary cultures of cerebellar granule cells clearly demonstrates that high-mo- 
lecular-weight species of VGF are excluded from neuronal processes, whereas the low-molecular-weight species of VGF are excluded from neuronal processes, whereas the low-molecular-weight forms are strongly enriched in secretory vesicles present in neurites. Accordingly, only the short peptides are released on cell depolarization. We have previously described that in PC12 cells secretory stimuli induce the release of VGF-90 and VGF-80 (Possenti et al., 1989), and we have also observed that every peptide recognized by anti-VGF frr-617 $_{17}$ serum in NGF-treated PC12 cells is released through the regulated pathway (authors' unpublished data). As mentioned before, NGF-treated PC1 2 cells produce such high quantities of this protein that the processing machinery of the cells may be saturated so that uncleaved VGF can escape from the compartment in which it should be processed. Alternatively, it is conceivable that secreted VGF has its own physiological role as suggested by the finding that the adrenal medulla does not process it. In this respect PCI 2 cells would behave like the chromaffin cells from which they are derived. The cleavages that produce the C-terminal-derived polypeptides should generate also proteins that are in principle detectable with antisera directed against $\mathrm{N}$-terminal domains of $\mathrm{VGF}$. Such species were undetectable; therefore, it is possible that they are rapidly degraded intracellularly. Another possible explanation is that the $\mathrm{C}$-terminal region of VGF contains a cis-acting signal for sorting the protein in the regulated secretory pathway. Once liberated the $\mathrm{N}$-terminal portions of the protein could be rerouted by default into the constitutive pathway and rapidly released into the extracellular medium. Such a situation has been described previously for the egglaying prohormone of Aplysia californica (Jung et al., 1993).

It has been shown that treatment with BFA by itself does not affect the morphology of mature synaptic vesicles localized in nerve terminals, whereas it induces redistribution of markers of early endosomes and of presumed immature synaptic vesicles (Mundigl et al., 1993). Moreover, BFA inhibits the formation of immature secretory granules but does not affect the regulated secretion from mature ones (Rosa et al., $1992 a$ ). In accord with these findings, the treatment of cerebellar granule cells with BFA does not inhibit secretion of prestored VGF-20, VGF-18, and VGF-10 (data not shown).

Several suggestions can be made regarding the possible biological role of the various species of VGF: We cannot exclude that other peptides, not detectable with the presently available antisera, are derived from VGF; further processing of the low-molecular-weight forms, leading to the removal of even a few residues at the C-terminus, will prevent their recognition by the antisera that we used. Nevertheless, because VGF-20, VGF-18, and VGF-10 are secreted by neuronal cells in culture on cell membrane depolarization, we are tempted to speculate that they are biologically relevant species that play a role in intercellular communication.

A recent article reports the purification, from bovine posterior pituitary, of a peptide corresponding to the C-terminal 30 amino acids of VGF (named peptide V) (Liu et al., 1994). The predicted molecular size of peptide $\mathrm{V}$ is $3,708 \mathrm{Da}$; therefore, it may represent a processed form different from those described in this article. We cannot exclude, however, that peptide V corresponds to VGF-10, because preliminary results indicate that recombinant peptides derived from the $\mathrm{C}$ terminus of VGF have an altered mobility in SDSPAGE.

Further studies will be necessary to ascertain if VGF-20, VGF-18, and VGF-10 have different targets or different functions as well as to determine if the high-molecular-weight VGF, as detected in the adult adrenal medulla, has its own biological role.

Acknowledgment: The authors wish to thank Dr. Delio Mercanti for invaluable suggestions and help and Drs. Cinzia Galli, Thomas Werge, Sergio Nasi, Loriana Castellani, and Fabio Benfenati for suggestions. We thank Dr. Paola Tirassa for technical support and Dr. Stanko S. Stojilkovic for the GT1-7 cell line. This work was supported by grants from CNR (Progetti Finalizzati Invecchiamento and ACRO).

\section{REFERENCES}

Burnette W. N. (1981) "Western blotting": electrophoretic transfer of protein from SDS-PAGE to unmodified nitrocellulose and radiographic detection with antibody and radio-iodinated protein A. Anal. Biochem. 112, 195-203.

Eboli M. L., Mercanti D., Ciotti M. T., Aquino A., and Castellani L. (1994) Glutamate-induced protein phosphorylation in cerebellar granule cells: role of protein kinase C. Neurochen. Res. 19, $1139-1146$.

Ferri G. L., Levi A., and Possenti R. (1992) A novel neuroendocrine gene product: selective VGF8a gene expression and immunolocalization of the VGF protein in endocrine and neuronal populations. Mol. Brain Res. 13, 139-143.

Ferri G. L., Gaudio R. M., Cossu M., Rinaldi A. M., Polak J. M., Berger P., and Possenti R. (1995) The "VGF" protein in rat adenohypophysis: sex differences. changes during the estrous cycle and after gonadectomy. Endocrinology 136, 2244-2251

Graham M. E. and Burgoyne R. D. (1993) Phosphoproteins of cultured cerebellar granule cells and response to the differentiationpromoting stimuli NMDA, high $\mathrm{K}^{+}$and ionomycin. Eur. J. Neurosci. 5, 575-583.

Greene L. A. and Tischler A. S. ( 1976 ) Establishment of a noradrenergic clonal line of rat adrenal pheochromocytoma cells which respond to nerve growth factor. Proc. Natl. Acad. Sci. USA 73, 2424-2428.

Hawley R. J., Sceibe R. J., and Wagner J. A. ( 1992 ) NGF induces the expression of the $\mathrm{VGF}$ gene through a cAMP response element. J. Neurosci. 12, 2573-2581.

Jung L. A., Kreiner T., and Scheller R. H. (1993) Expression of mutant ELH pro-hormone in AtT-20 cells: the relationship between prohormone processing and sorting. J. Cell Biol. 121, $12-21$.

Klausner R. D., Donaldson J. G., and Lippincott-Schwartz J. ( 1992) Brefeldin $A$ : insights into the control of membrane traffic and organelle structure. J. Cell Biol. 116, 1071-1080.

Laemmli U. K. (1970) Cleavage of structural proteins during the assembly of the head of bacteriophage T. Nature 227, 680 685. 
Levi A., Eldridge J. D., and Paterson B. M. ( 1985 ) Molecular cloning of a gene sequence regulated by nerve growth factor. Science 229, 393-395.

Levi G. and Ciotti M. T. (1983) Glutamate and GABA localization and evoked release in cerebellar cells differentiating in culture, in Glutamine, Glutamate and GABA in the Central Nervous Svitem (Hertz L.. Kvamme E., McGeer E. G., and Schousboe A., eds), pp. 493-508. Alan R. Liss, New York.

Levi G., Aloisi F., Ciotti M. T., and Gallo V. (1984) Autoradiographic localization and depolarization-induced release of acidic amino acids in differentiating granule cultures. Brain Res. 290, $77-86$.

Liu J.-W., Andrews P. C., Mershon J. L., Yan C., Allen D. L., and Ben-Jonathan N. (1994) Peptide V: a VGF derived neuropeptide purified from bovine posterior pituitary. Endocrinology 135 , $2742-2748$.

Lombardo A., Rabacchi S. A., Cremisi F., Pizzorusso T., Cenni C. M., Possenti R., Barsacchi G., and Maffei L. (1995) A developmentally regulated nerve growth factor-induced gene, VGF, is expressed in geniculocortical afferents during synaptogenesis. Neuroscience 65, 997-1008.

Lowry O. H., Rosebrough N. J., Farr A. L., and Randall R. J. (1951) Protein measurement with the Folin phenol reagent. $J$. Biol. Chem. 193, 265-275.

Mahata M., Hörtnagl H., Mahata S. K., Fischer-Colbrie R., and Winkler H. ( 1993 ) Messenger RNA levels of chromogranin B, secretogranin II, and VGF in rat brain after AF64A-induced septohippocampal cholinergic lesions. J. Neurochem. 61, 1648 1656.

Mahata S. K., Mahata M., Fischer-Colbrie R., and Winkler H. (1993a) In situ hybridization: mRNA levels of secretogranin II, VGF and peptidylglycine alpha-amidating monooxygenase in brain of salt-loaded rats. Histochemistry 99, 287-293.

Mahata S. K.. Mahata M., Hörtnagl H., Fischer-Colbrie R., Dietze O., and Winkler H. (1993b) Concomitant changes of messenger ribonucleic acid levels of secretogranin II, VGF, vasopressin and oxytocin in the paraventricular nucleus of rats after adrenalectomy and during lactition. J. Neuroendocrinol. 5, 323-330.

Mercanti D., Galli C., Liguori M., Ciotti M. T., Gullà P., and Calissano P. (1992) Identification of the serum complex which induces cerebellar granule cell in vitro differentiation and resistance to excitatory amino acids. Eur. J. Neurosci. 4, 733-744

Molloy S. S., Thomas L., VanSlyke J. K., Stenberg P. E., and
Thomas G. (1994) Intracellular trafficking and activation of the furin proprotein convertase: localization to the TNG and recycling from the cell surface. $E M B O J .13,18-33$.

Mundigl O., Matteoli M., Daniell L., Thomas-Reetz A., Metcalf A., Jahn R., and De Camilli P. (1993) Synaptic vesicle proteins and early endosomes in cultured hippocampal neurons: differential effects of brefeldin $\mathrm{A}$ in axons and dendrites. $J$. Cell Biol. 122, $1207-1221$.

Possenti R., Eldridge J. D., Paterson B. M., Grasso A., and Levi A. (1989) A protein induced by NGF in PC12 cells is stored in secretory vesicles and released through the regulated pathway. EMBO J. 8, 2217-2223

Robinson M. S. and Kreis T. E. (1992) Recruitment of coat proteins onto Golgi membranes in intact and permeabilized cells: effect of brefeldin $\mathrm{A}$ and $\mathrm{G}$ protein activators. Cell 69, 129-138.

Rosa P., Barr F. A., Stinchcombe J. C., Binacchi C, and Huttner W. B. ( $1992 a$ ) Brefeldin A inhibits the formation of constitutive secretory vesicles and immature secretory granules from the trans-Golgi network. Eur. J. Cell Biol. 59, 265-274.

Rosa P., Mantovani S., Rosboch R., and Huttner W. B. (1992b) Monensin and brefeldin A differentially affect phosphorylation and sulfation of secretory proteins. J. Biol. Chem. 267, 1222712232.

Salton S. R. J., Fischberg D. J., and Dong K. (1991) Structure of the gene encoding VGF, a nervous system-specific mRNA that is rapidly and selectively induced by nerve growth factor in PC12 cells. Mol. Cell. Biol. 11, 2335-2349.

Sisk W. P., Chirikjian J. G.. Lautenberger J., Jorcyk C., Papas T. S., Berman M. L., Zagursky R., and Court D. L. (1986) A plasmid vector for cloning and expression of gene segments: expression of an HTLV-1 envelope gene segment. Gene 48, 183-193.

Steiner D. F., Smeekens S. P., Ohagi S., and Chan S. J. (1992) The new enzymology of precursor processing endoproteases. J. Biol. Chem. 267, 23435-23438.

van den Pol A. N., Decavel C., Levi A., and Paterson B. (1989) Hypothalamic expression of a novel gene product, VGF: immunocytochemical analysis, $J$ Neurosci 9, 4122-4137.

van den Pol A. N., Bina K.. Decavel C., and Ghosh P. (1994) VGF expression in the brain. J. Comp. Neurol. 347, 455-469.

Xu H. and Shields D. (1993) Prohormone processing in the transGolgi network: endoproteolytic cleavage of prosomatostatin and formation of nascent secretory vesicles in permeabilized cells. J. Cell Biol. 122, 1169-1184 